\title{
Factors related to psychopathological symptoms of female inmates of a prison in Lima
}

\author{
Esteban-Febres S, Enoki-Miñano K, Escudero-Moreira T, \\ La Cunza-Peña M, Quispe-Gutiérrez Y \\ Psychology Unit of the Virgen de Fátima Prison, Lima (Peru)
}

\begin{abstract}
Objectives: The objective is to know the relationship between age, time of incarceration, juridical situation, activity in prison, penitentiary classification and having or not children under eighteen years old, with the incidence of psychopathological symptoms of female inmates from a penitentiary in Lima.

Materials and methods: The SCL-90-R was used to determinate the psychopathological symptoms in 388 female inmates. Correlations and comparisons were made.

Results: Results show low negative correlation between age and depression, anxiety, hostility, psychoticism and PST; time of incarceration has a low negative correlation with depression, paranoid ideation and GSI. Comparisons show significant differences according juridical situation in interpersonal sensibility, depression, paranoid ideation, GSI and PSDI. According activity in prison differences were found in somatization, depression, anxiety, psychoticism, PST and GSI; and, according penitentiary classification differences were found in somatization, obsession compulsion, interpersonal sensibility, depression, anxiety, paranoid ideation, psychoticism, PST, GSI and PSDI. There were not differences between inmates with or without children under eighteen years old.

Discussion: No overcrowding, accessibility of treatment, and cultural differences are related to the low scores obtained. The low correlations might be related to intermediate variables that were not observed and its recommended to observe in future research.
\end{abstract}

Keywords: prisons, women, surveys and questionnaires, psychopathology, mental health, depression, classification, statistics, nonparametric.

Text received: 29/12/2017

Text acepted: 25/05/2018

\section{INTRODUCTION}

The state of mental health in prisons is an issue that has hardly been studied in Peru, mostly because there are more urgent problems to consider in the prison context, such as overcrowding, criminal conduct and increased sentences for criminals, that are a cause of greater concern to the authorities managing the Peruvian prison system. However, the accelerated growth of the prison population in the last ten years, from 37,445 in $2006^{1}$ to 77,298 in January $2016^{2}$, has led to overcrowding and highlighted the existence of inmates with mental diseases who require specialised care.
Bustamante et al. ${ }^{3}$ comment that losing one's freedom is a traumatic experience, and if the characteristic features common to prisons are added (such as saturation, stressful environment, involuntary cohabitation, scarce resources, etc.), an environment is created where mental disorders can appear.

In 2007, a study on mental health in prisons in Lima ${ }^{4}$ indicated that the psychopathological symptoms measured with the Symptom Checklist 90-R $(S C L-90-R)$, significantly exceeded the scores expected in a normal population, where the scales of psychosis and somatisation were especially high, as were the intensity of psychological suffering and the 
extent of high positive symptoms. Rivera-Ledesma et al. ${ }^{5}$ indicate that women generally tend to score more highly on the SCL-90-R than men, while a similar pattern is observed when other instruments for measuring mental health are used ${ }^{6}$.

In the case of female inmates of Peruvian prisons, ignorance about the characteristics of mental health is greater, due to the fact that they make up only $5.9 \%$ population of a total of 77,242 inmates, according to the statistics of the National Prisons Institute 2 .

There are gender differences between men and women when they enter prison. Herrera et al. ${ }^{7}$ point out that women suffer more in prison because their confinement directly affects the family nucleus, given that they are often the affective and economic foundation of the family. Such a situation means that a female inmate often experiences symptoms of depression and anxiety. De Miguel $^{8}$ comments that the mental health of women in prisons is more negatively affected than that of men, since more than half of female inmates have reported symptoms of depression, stress and claustrophobia, and that during their stay, three quarters of female inmates report symptoms of anxiety. Some research work ${ }^{9}$ indicates that with regard to psychopathology, $44 \%$ of women in prison meet the criteria of a clinical case, in which depression, somatisation, obsessive-compulsive disorder and paranoid ideations predominate.

It can be seen therefore that gender inequality has a negative influence on women's mental health, since despite their greater participation in the labour market, they continue to have more responsibilities in terms of caring for and running the family than men $^{10}$.

It can be observed that the psychological distress amongst female inmates tends to be experienced with greater intensity when they enter prison and are separated from their family of origin. This situation can change as time passes in prison, as Iversen et al propose ${ }^{11}$, who found spending more time in prison is a predictor of the inmates perceiving a good state of health.

The relation between age and the presence of psychopathological symptoms has not been covered in studies with inmates either. Some investigations indicate that young people tend to present a larger number of psychopathological symptoms than older people ${ }^{12}$, with the exception of older adults ${ }^{13}$.

The classification and allocation of inmates to a prison in Peru is regulated by regulations and directives that take into consideration the level of danger of the female inmate and if she is pregnant or the mother of small children. For this reason there are prisons that house female inmates who require minimal, medium and maximum security and who have difficulties in readapting. When the inmate enters the prison, she is classified once again by a Technical Classification Committee, where after considering a series of legal, social and psychological variables, she is assigned to a regime that may be minimum, medium or maximum security. As the Peruvian prison systems is a progressive one, after a year and a half and with positive treatment evaluations, the inmate may progress to a lower level of security.

The aim of this study is to determine the relation between age, period of confinement, the legal situation of the female inmate, activities taking place in the prison, the stage of classification of the inmate and motherhood of small children, with the incidence of psychopathological symptoms amongst the female inmates of the Virgen de Fátima model prison.

\section{METHODS}

This study took place in the Virgen de Fátima model prison, which was opened in December 2008, to house minimum and medium security female inmates. Its population of 371 inmates, and is characterised by not being overpopulated and for being a prison with the status of school-workshop, where the prisoners spend time studying or working, and there are few inmates who spend time in these activities. This may be due to the fact that there are inmates who think that as they do not have a sentence, they will not be in prison for long ${ }^{14}$. Other causes are: withdrawal of workshop activities for disciplinary offences, no interest in participation or lack of vacant places in some workshops.

\section{Participants}

So as not to affect the results, five female inmates who presented a diagnosis of psychopathological disorder given by the consultant psychiatrist were excluded because of the very high scores they had. Likewise, given that the study was a voluntary one, 28 inmates refused to participate which left a final sample of 338 inmates.

The participants were assessed in December 2015 by the psychologists responsible for the modules where they were located, who after explaining the purposes of the study and the fact that it was anonymous, asked for the informed consent of the participating inmates. 


\section{Instruments}

The Symptom Checklist $90-R$ (SCL-90-R) is a self-completed list whose aim is to identify symptoms grouped into dimensions, evaluating the intensity of psychological distress on a scale that ranges from 0 or "nothing" up to 4, or "very much or extremely". This instrument is very widely used as a screening method to monitor cases and evaluate symptomatic changes under different treatments. It consists of 90 items grouped into nine dimensions: somatisation, obsession-compulsion, interpersonal sensitivity, depression, anxiety, hostility, phobic anxiety, paranoid ideation and psychoticism. It has three global indices, which are: global wellness, hardiness and symptom free.

The SCL-90-R has been widely used internationally and in Spanish speaking countries, and studies have been conducted on its validity and reliability in such contexts ${ }^{15}$. As regards its use on the Peruvian general public, Ponce $^{16}$ (2015) demonstrates that there is a high level of reliability via the internal consistency in the nine scales $(\alpha=0.72-0.85)$ and indicates that the item-test validity is between 0.34-0.64. In the Peruvian prison context, Esteban et al.4 found a reliability of $\alpha=0.63-0.83$ in each dimension and showed an acceptable validity with the use of the factor analysis method.

\section{Procedure}

A descriptive analysis of the categorical and numerical variables was carried out. The Kolmogórov-Smirnov test was also run with Lilliefors' significance correction determine the normality of the variables to be correlated.

Given that not all the variables follow a normal distribution, Spearman's rank correlation coefficient was applied to correlate the variables of age and confinement period with the scores of the SCL-90-R scales.

To analyse the categorical variables, the MannWhitney $U$ test was used to determine if there were differences according to the legal situation (two categories); and the Kruskal-Wallis test in the case of the occupation variable (three categories).

\section{RESULTS}

The socio-demographic characteristics of the inmates showed that according to the legal situation, $71.3 \%$ are sentenced $(241)$ and $28.7 \%$ are indicted (97). The activities taking place in the prison showed that $59.2 \%$ are studying (200), $29.3 \%$ are working
(99), and $11.5 \%$ do not work or study (39). As regards classification, $45.9 \%$ are in a minimum security environment, and $54.1 \%$, in medium security modules (183). It was also observed that $63.3 \%$ have children under age (214), while $36.7 \%$ do not (124).

The description of the variables of age, period of confinement, sentence time and scores from the SCL90-R can be seen in Table 1, which showed that when the normality analysis was carried out using the Kolmogórov-Smirnov test, it was seen that only the age variable followed a normal distribution.

The analysis of the correlations between variables using Spearman's test shows that age is negatively and weakly correlated with the dimensions: depression $(\mathrm{r}=-0.129, \mathrm{p}<0.05)$, anxiety $(\mathrm{r}=-0.127, \mathrm{p}<0.05)$, hostility $(\mathrm{r}=-0.151, \mathrm{p}<0.01)$, psychoticism $(\mathrm{r}=-0.107$, $\mathrm{p}<0.05)$ and PST $(\mathrm{r}=-0.158, \mathrm{p}<0.01)$. The time of confinement had a highly significant weak negative correlation with the scales of depression $(r=-.175, \mathrm{p}<0.01)$, and paranoid ideation $(\mathrm{r}=-0.169, \mathrm{p}<0.01)$ and PSDI $(\mathrm{r}=-0.204, \mathrm{p}<0.01)$.

The results indicate that, in accordance with the legal situation, indicated inmates present higher ave-

Table 1. Descriptive statistical data of the variables of age, time of confinement and scores of the SCL-90-R.

\begin{tabular}{|c|c|c|c|c|}
\hline & Minimum & Maximum & Median & $\begin{array}{l}\text { Typ. } \\
\text { dev. }\end{array}$ \\
\hline Age & 19 & 70 & 39.60 & 10.676 \\
\hline $\begin{array}{l}\text { Time of } \\
\text { confinement } \\
\text { in months }\end{array}$ & 01 & 174 & 35.24 & 27.531 \\
\hline Somatisation & .00 & 3.50 & 0.87 & 0.636 \\
\hline Obsessive & .00 & 3.90 & 0.821 & 0.534 \\
\hline $\begin{array}{l}\text { Interpersonal } \\
\text { sensitivity }\end{array}$ & .00 & 3.22 & 0.531 & 0.488 \\
\hline Depression & .00 & 3.23 & 0.847 & 0.530 \\
\hline Anxiety & .00 & 3.00 & 0.602 & 0.540 \\
\hline Hostility & .00 & 4.00 & 0.371 & 0.514 \\
\hline Phobia & .00 & 3.00 & 0.440 & 0.454 \\
\hline Paranoid & .00 & 3.00 & 0.674 & 0.539 \\
\hline Psychoticism & .00 & 3.30 & 0.395 & 0.400 \\
\hline PST & .00 & 90.00 & 38.524 & 18.077 \\
\hline GSI & .00 & 2.81 & 0.660 & 0.431 \\
\hline PSDI & .00 & 4.00 & 1.466 & 0.462 \\
\hline
\end{tabular}

Note. GSI: Global Severity Index. PSDI: Positive

Symptom Distress Index. PST: Positive Symptom Total. 
Esteban-Febres S, Enoki-Miñano K, Escudero-Moreira T, La Cunza-Peña M, Quispe-Gutiérrez Y.

Factors related to psychopathological symptoms of female inmates of a prison in Lima.

Table 2. Difference between SCL-90-R scores according to activity*

\begin{tabular}{|c|c|c|c|c|c|c|}
\hline & \multicolumn{3}{|c|}{ Average rank } & \multirow[b]{2}{*}{$\mathrm{X}^{2}$} & \multirow[b]{2}{*}{$\mathrm{gl}$} & \multirow[b]{2}{*}{ Sig. asymp } \\
\hline & Education & Work & $\begin{array}{c}\text { Does not work } \\
\text { or study }\end{array}$ & & & \\
\hline Age & 162.425 & 170.025 & 204.449 & 6.056 & 2 & 0.048 \\
\hline Time of confinement in months & 163.793 & 179.096 & 174.410 & 1.743 & 2 & 0.418 \\
\hline Somatisation & 161.593 & 180.172 & 182.962 & 3.264 & 2 & 0.195 \\
\hline Obsessive & 154.703 & 179.399 & 220.256 & 16.179 & 2 & 0.000 \\
\hline Interpersonal sensitivity & 155.018 & 182.247 & 211.410 & 13.338 & 2 & 0.001 \\
\hline Depression & 160.510 & 182.081 & 183.667 & 4.394 & 2 & 0.111 \\
\hline Anxiety & 164.965 & 179.657 & 166.974 & 1.561 & 2 & 0.458 \\
\hline Hostility & 166.883 & 167.439 & 188.154 & 1.636 & 2 & 0.441 \\
\hline Phobia & 163.428 & 167.732 & 205.128 & 6.079 & 2 & 0.048 \\
\hline Paranoid & 158.435 & 183.505 & 190.692 & 6.435 & 2 & 0.040 \\
\hline Psychoticism & 158.460 & 179.657 & 200.333 & 7.507 & 2 & 0.023 \\
\hline PST & 162.100 & 171.232 & 203.051 & 5.778 & 2 & 0.056 \\
\hline \multicolumn{7}{|l|}{ GSI } \\
\hline PSDI & & & & & & \\
\hline
\end{tabular}

Note. **Kruskal Wallis test.

GSI: Global Severity Index. PSDI: Positive Symptom Distress Index. PST: Positive Symptom Total.

Table 3. Differences between SCL-90-R scores according to inmate classification.

\begin{tabular}{|c|c|c|c|c|c|}
\hline & & Sum of ranks & $\bar{U}$ & $\mathrm{Z}$ & Asy. (bil) sig. \\
\hline Somatisation & $\begin{array}{l}\text { Minimum security } \\
\text { Medium security }\end{array}$ & $\begin{array}{l}23,067.5 \\
34,223.5\end{array}$ & $10,977.5$ & -3.59 & 0.000 \\
\hline Obsessive & $\begin{array}{l}\text { Minimum security } \\
\text { Medium security }\end{array}$ & $\begin{array}{l}24,167 \\
33,124 \\
\end{array}$ & 12,077 & -2.36 & 0.018 \\
\hline Interpersonal Sensitivity & $\begin{array}{l}\text { Minimum security } \\
\text { Medium security }\end{array}$ & $\begin{array}{l}24,357.5 \\
32,933.5\end{array}$ & $12,267.5$ & -2.15 & 0.032 \\
\hline Depression & $\begin{array}{l}\text { Minimum security } \\
\text { Medium security }\end{array}$ & $\begin{array}{l}23,011 \\
34,280 \\
\end{array}$ & 10,921 & -3.65 & 0.000 \\
\hline Anxiety & $\begin{array}{l}\text { Minimum security } \\
\text { Medium security }\end{array}$ & $\begin{array}{l}23,184 \\
34,107\end{array}$ & 11,094 & -3.46 & 0.001 \\
\hline Hostility & $\begin{array}{l}\text { Minimum security } \\
\text { Medium security }\end{array}$ & $\begin{array}{l}24,896,5 \\
32,394,5 \\
\end{array}$ & $12,806.5$ & -1.58 & 0.114 \\
\hline Phobic & $\begin{array}{l}\text { Minimum security } \\
\text { Medium security }\end{array}$ & $\begin{array}{l}24,929 \\
32,362 \\
\end{array}$ & 12,839 & -1.52 & 0.129 \\
\hline Anxiety & $\begin{array}{l}\text { Minimum security } \\
\text { Medium security }\end{array}$ & $\begin{array}{l}23,944,5 \\
33,346,5\end{array}$ & $11,854.5$ & -2.62 & 0.009 \\
\hline Paranoid Ideation & $\begin{array}{l}\text { Minimum security } \\
\text { Medium security }\end{array}$ & $\begin{array}{l}24,333 \\
32,958 \\
\end{array}$ & 12,243 & -2.18 & 0.029 \\
\hline PST & $\begin{array}{l}\text { Minimum security } \\
\text { Medium security }\end{array}$ & $\begin{array}{l}23,602 \\
33,689\end{array}$ & 11,512 & -2.98 & 0.003 \\
\hline GSI & $\begin{array}{l}\text { Minimum security } \\
\text { Medium security }\end{array}$ & $\begin{array}{l}23,153 \\
34,138\end{array}$ & 11,063 & -3.49 & 0.000 \\
\hline PSDI & $\begin{array}{l}\text { Minimum security } \\
\text { Medium security }\end{array}$ & $\begin{array}{l}22,941 \\
34,350\end{array}$ & 10,851 & -3.72 & 0.000 \\
\hline
\end{tabular}

Note. GSI: Global Severity Index. PSDI: Positive Symptom Distress Index. PST: Positive Symptom Total. 
rage ranks than sentenced inmates, with significant differences being found using the Mann-Whitney U test on the scales of interpersonal sensitivity $(\mathrm{Z}=-2.22$, $\mathrm{p}<0.026)$, depression $(Z=-3.21, p<0.001)$, paranoid ideation $(Z=-2.71, p<0.007)$, GSI $(Z=-2.05, p<0.040)$, and PSDI $(Z=-3.48, p<0.001)$.

Table 2 shows that the activities carried out by the inmates determines statistically significant differences in the scores for somatisation, depression, anxiety, psychoticism, PST and GSI, and it was observed that the lowest average ranks correspond to inmates in education and the highest scores matched inmates that did not work or study.

The inmate's classification also determined differences in the scores obtained on the scales of the SCL-90-R. Table 3 shows that inmates classified for a medium security module show significantly higher average scores than the ones classified for a minimum security module in the scales of somatisation, obsession-compulsion, interpersonal sensitivity, depression, anxiety, paranoid ideation, psychoticism, PST, GSI and PSDI.

No significant differences were found when inmates with under-age children were compared to those who had none.

\section{DISCUSSION}

The results obtained with the SCL-90-R help to determine the mental health situation of female inmates in a model prison in Lima, where variables such as overcrowding and lack of access to prison treatment (educational workshops, occupational workshops, psychological, legal and social assistance) are controlled. We expected to obtain results similar to those obtained by Kendal ${ }^{17}$, who found a deterioration in the mental health of female inmates at a women's prison in Lima, with a predominance of severe depression; however, the averages extracted in this study are lower than the ones obtained in the prison population by Esteban et al. ${ }^{4}$, (with the exception of somatisation and phobic anxiety) and by Villagra et al. ${ }^{9}$ This result may be linked to characteristics such as sufficient space and access to prison treatment and their influence on the intensity of the psychopathological symptoms.

When comparisons are made of the medians obtained in this study and those of a normal population, what is observed is that the inmates have higher scores than those obtained by González de Rivera et al. ${ }^{18}$ in 2002, with the exception of the hostility dimension, where the scores for Spanish women are higher. The low scores in hostility for the inmates may be due to socio-cultural differences between both countries, especially in aspects of the family and gender roles, where Peruvian society is more traditional19 and women tend to adopt feminine attitudes that are incompatible with hostility.

The high average in the inmates' somatisation and phobic anxiety is repeated when compared with the non-clinical sample of Abuín et al. ${ }^{20}$ Apparently, the psychosomatic symptoms (which may reflect an underlying medical pathology) and phobic symptoms (fear and avoiding activities) receive greater social acceptance as a way of expressing distress inside prison and, above all, are functional in interactions between inmates and prison staff.

The correlation of age with symptomatic dimensions showed that five dimensions (depression, anxiety, hostility, psychoticism and PST) had a weak negative correlation with this variable. This indicates that the younger inmates present more symptoms in these dimensions than the older inmates. These findings match those of Casullo et al. ${ }^{12}$ However, considering that the relation found is a weak one, the presence of other unobserved variables related to age, such as level of coping skills, may be intuited.

The confinement time in months also showed a weak negative relation with the dimensions of depression, paranoid ideation and PSDI, indicating that the inmates with less time in prison usually experience more distress in such dimensions. Evidently, admission into a prison, as stated by Bustamante et al. ${ }^{3}$, is a traumatic event. Crying and distrust reduce in intensity in line with the time spent by the inmate in prison, as she assimilates the experience and cohabitation with other inmates, which have an influence on the reduction of psychopathological distress.

The inmate's legal situation is a factor related to the presence of psychopathological symptoms, since significant differences were found between the inmates that had a final sentence and those that were in custody (under process of investigation, with custody or appeal order). Inmates in custody tend to obtain higher scores in the scales of the SCL-90-R, due to the fact that expectations are generated as to the outcome of the court proceeding, which products hyper-sensitivity to external opinions, depression, mistrust, and is reflected in the significantly high scores obtained in 
the scales of interpersonal sensitivity, depression, paranoid ideation, GSI and PSDI. The type of expectations regarding their sentence is a variable that should be studied in detail, given that negative expectations about the result of their trial may come into play.

Participation in activities such as educational and occupational workshops is a factor that contributes towards inmates mental health. When the groups of inmates who study or work were compared with those who do not, it was seen that the latter groups tend to obtain high scores in the SCL-90-R. However, when the Kruskal-Wallis test was used to analyse the averages in the three groups, the only significant differences were found in the dimensions of somatisation, depression, anxiety, psychoticism, PST and GSI. It may be concluded that the inmates that study present fewer psychopathological symptoms than those that work and those that do not participate in any of the activities, probably because the inmates who study have a less demanding timetable than the ones who work, which enables them to allocate more of their time to leisure activities; while the working inmates have to certify eight hours of work, productivity make monthly payments for administrative items in their workshops. According to Mapelli et al. ${ }^{21}$, more female inmates get involved in occupational activities than men, since they regard studying or working as a therapeutic activity that helps to keep them occupied, forget about their problems and make time pass quicker, which may explain the fact that the inmates who do not work or study obtain high scores in the SCL-90-R.

The type of prison regime into which the inmate is classified also determines differences between inmates. It was found that minimum security inmates present significantly lower scores than medium security prisoners in seven dimensions of the SCL-90-R: somatisation, obsession-compulsion, interpersonal sensitivity, depression, anxiety, paranoid ideation, psychoticism, and in all the global scores of the scale: PST, GSI and PSDI. These differences, in concordance with the variables that have an influence on the imprisonment process defined by Quintero-Cárdenas et al. ${ }^{22}$, may be due to the fact that minimum security inmates generally have more confinement time, are serving a sentence, participate in educational or occupational workshops, and are usually older than the medium security inmates.

Herrera et al. ${ }^{7}$ indicates that imprisonment has a greater impact on women because they are the ones that most frequently take on the family roles, especially women with children, as observed by Mignon23 in mothers confined in maximum security prisons. The results obtained do not confirm this hypothesis, as no significant differences were found in the scores obtained by the inmates with under-age children and those that did not. The influence of this variable may be attenuated by other variables, such as time of confinement of inmates and participation in educational and occupational workshops.

Depression is the symptom that most often appears on admission to a prison8, and it is the only variable that was seen to be present in all the correlations and comparisons made, which makes it necessary to carry out more studies that consider the incidence and evolution of depression in the female prison population.

\section{CORRESPONDENCE}

\author{
Silvia Evelyn Esteban Febres \\ Establecimiento Penitenciario Virgen de Fátima. \\ Lima (Perú) \\ E-mail: estebanfebres19@gmail.com
}

\section{REFERENCES}

1. Coordinadora Nacional de Derechos Humanos. Las cárceles en el Perú: manifiesta incompatibilidad con los principios constitucionales. [Internet]. En: Informe anual 2014-2015. Perú; 2015. p. 108-15. [citado 25 Abr 2016]. Disponible en: http://derechoshumanos.pe/informe2014_15/Sistema_Penitenciario_2014_15.pdf

2. Informe estadístico penitenciario 2016. [Internet]. Perú: Instituto Nacional Penitenciario; 2016. [citado 10 May 2016]. Disponible en: https://www. inpe.gob.pe/informe-2016.html

3. Bustamante R, Paredes-Carbonell JJ, Aviñó D, González J, Pitarch C, Martínez L, et al. Participatory design guide for mental health promotion in prisons. Rev Esp Sanid Penit. 2013;15:44-53.

4. Esteban S, Reyes S, Charcape E. Diagnóstico de salud mental en internos de establecimientos penitenciarios de Lima. Lima: Instituto Nacional Penitenciario; 2007.

5. Rivera-Ledesma A, Caballero N, Pérez I, Montero-López M. SCL-90 R: Psychological Distress, Gender and Risky Behaviors. Univ Psychol. 2013 [citado 11 Abr 2017];12:105-118. Disponible en 
http://www.scielo.org.co/scielo.php?script=sci_ arttext\&pid=S1657-92672013000100011\&lng=en $\& \ln g=e n$

6. Lynch SM, Fritch A, Heath, NM. Looking beneath the surface: The nature of incarcerated women's experiences of interpersonal violence, treatment needs, and mental health. Feminist Criminology. 2012;7:381-400.

7. Herrera MC, Expósito F. Una Vida entre Rejas: Aspectos Psicosociales de la Encarcelación y Diferencias de Género. Psychosocial Intervention. 2010 [citado 25 Abr 2016];19:235-41. Disponible en: http://www.redalyc.org/articulo. oa?id=179817507004

8. De Miguel E. El encierro carcelario. Impacto en las emociones y los cuerpos de las mujeres presas. Cuadernos de Trabajo Social. 2014 [citado 19 Ago 2016];27:395-404. Disponible en: http:// revistas.ucm.es/index.php/CUTS/article/viewFile/43821/44556

9. Villagra P, González A, Fernández P, Casares MJ, Martín JL, Rodríguez F. Perfil adictivo, delictivo y psicopatológico de una muestra de mujeres en prisión. 2011 [citado 22 Ago 2016];23:219-26. Disponible en: http://m.adicciones.es/index.php/ adicciones/article/viewFile/146/146

10. Manuela Ramos. Mujeres, Salud Mental y género. [Internet]. Lima: Manuela Ramos; 2015. [citado $10 \mathrm{Jul}$ 2016]. Disponible en: http://www.manuela. org.pe/wp-content/uploads/2011/09/64025569Documento-de-Trabajo-01-Salud-mental-mujeres-y-genero.pdf

11. Iversen, VC, Sam DL, Helvik AS. Psychological distress and perceived health in inmates in Norwegian prisons. Scand J Public Health. 2014;42:171176. Epub 20132 Oct.

12. Casullo MM, Morandi P, Donati F. Síntomas psicopatológicos, predisposición a perdonar y religiosidad en estudiantes universitarios. [Internet]. Anu Investig. 2006 [citado 23 Ago 2016];13:261-6. Disponible en: http://www. scielo.org.ar/scielo.php?script=sci_arttext\&pid $=$ S1851-16862006000100026

13. Westerhof GJ, Keyes CLM. Mental Illness and Mental Health: The Two Continua Model Across the Lifespan. [Internet]. J Adult Dev. 2010 [citado 11 Ago 2016];17:110-9. Disponible en: https://www.ncbi.nlm.nih.gov/pmc/articles/ PMC2866965/pdf/10804_2009_Article_9082. pdf

14. Meyer CR, Tangney JP, Stuewing J, Moore KE. Why Do Some Jail Inmates Not Engage in Treatment and Services? Int J Offender Ther Comp Criminol. 2014 [citado 10 Nov 2016 ];58:914-30. Disponible en: https://www.ncbi. nlm.nih.gov/pmc/articles/PMC4794253/

15. Ignatyev $Y$, Fritsch R, Priebe $S$, Mundt AP. Psychometric properties of the symptom checklist-90-R in prison inmates. Psychiatry Research. 2016 [citado 18 Mar 2017];239:226-31. Disponible en: http://www.psy-journal.com/article/S01651781(15)30068-8/fulltext

16. Ponce C. Dimensiones sintomáticas psicopatológicas en conductores de Lima Metropolitana. Liberabit. 2015 [citado 8 Sep 2016];21:153-65. Disponible en: http://www.scielo.org.pe/pdf/liber/ v21n1/a14v21n1.pdf

17. Kendal RC. Experiencia carcelaria y salud mental en mujeres peruanas privadas de libertad penal de Chorrillos: Lima, 2008. [Tesis de maestría]. Universidad Nacional Mayor de San Marcos: Lima; 2010. [citado 20 Oct 2016]. Disponible en: http:// cybertesis.unmsm.edu.pe/handle/cybertesis/2531

18. González de Rivera JL, De las Cuevas C, Rodríguez M, Rodríguez F. SCL-90-R Cuestionario de 90 síntomas. Manual Adaptación Española. Madrid: TEA Ediciones; 2002.

19. Instituto de Opinión Pública de la Pontificia Universidad Católica del Perú. Familia, Roles de Género y Violencia de Género. Lima: Pontificia Universidad Católica del Perú; 2014. Disponible en: http://repositorio.pucp.edu.pe/index/bitstream/ handle/123456789/36496/IOP_1212_01_R_4. pdf?sequence $=18$ is Allowed $=y$

20. Abuín MR, De Rivera L. Dependency, detachment and psychopathology in a nonclinical sample: General relations and gender differences. Is there a new line of inquiry on paranoid pathology? Clin Sal. 2015 [citado 10 Abr 2018];26:65-72. Disponible en: http://dx.doi.org/10.1016/j.clysa.2015.06.003

21. Mapelli B, Herrera M, Sordi B. La exclusión de las excluidas. ¿Atiende el sistema penitenciario a las necesidades de género?: Una visión andaluza. Estud Pen Criminol. 2013;33:59-95.

22. Quintero-Cárdenas CJ, Jiménez-Molina JR, Riaño-Martínez MI, Zúñiga-Barros IA. Sintomatología psicológica en población reclusa del establecimiento carcelario de Bogotá. Cuadernos Hispanoamericanos de Psicología. 2015;15:53-66.

23. Mignon S. Health issues of incarcerated women in the United States. Ciênc Saúde Coletiva. 2016;21:2051-9. 